\title{
US privacy laws may curb access to medical data
}

[WASHINGTON] Moves in the United States to legislate on medical privacy are creating a heated debate between researchers and privacy advocates about the conditions under which scientists should have access to medical records and archives of tissue samples. At stake is the relatively liberal access to such material that researchers currently enjoy.

Under the Health Portability and Accountability Act of 1996, Donna Shalala, Health and Human Services Secretary, has until August to make "detailed recommendations" on medical privacy to Congress. If Congress does not produce legislation based on these recommendations by August 1999, Shalala must issue regulations, although their scope would be narrower, being restricted to financial and administrative transactions.

At present, medical privacy is not governed by any comprehensive federal law, although specific laws apply to some federal government programmes. But state laws on privacy, and the use of genetic information, are proliferating. A uniform federal law would bring greater coherence, argue some scientists.

A subcommittee of President Bill Clinton's National Bioethics Advisory Commission is also expected later this year to make recommendations on the use of the tens of millions of archived tissue samples, collected from autopsies, biopsies and surgery across the United States. The outcome of the debate is expected to be new federal legislation.

At present, nominative tissue samples can be used by researchers if they can persuade local ethics committees - called institutional review boards - that nominative data is essential to a study, and that its use will not harm subjects.

Many scientists argue that such access is critical to much beneficial research. Oncogenes that could be used as diagnostic or prognostic markers might be identified from stored tumour samples, for example, but that requires access to patient records showing disease outcome. The link between vaginal cancer in young women and use of diethylstilbesterol by their mothers was also established through identifiable archived specimens.

But privacy advocates argue that the risk to patients of sensitive information falling into the wrong hands outweighs the interest of scientists. James Pyles of the Coalition for Patient Rights recently told the subcommittee of the National Committee on Vital and Health Statistics that is advising Shalala on medical privacy that "simply because someone can think of a reason why they need identifiable health information to provide better health care doesn't mean they have a right to it or should be able to get it without consent".
Robert Gellman, a medical privacy consultant who is chair of the subcommitee, says: "It is an open question whether researchers will be able to get access to identifiable records at all - and even in some proposals non-identifiable [records]."

An expert panel convened by the National Heart, Lung and Blood Institute is this month expected to recommend that use of identifiable samples in an institute repository of 2.3 million blood samples requires informed consent, unless the research concerns the blood safety issues for which the samples were collected.

But a statement issued last year by 17 scientific groups convened by the College of American Pathologists argues that nominative samples should be available without consent for research approved by institutional review boards, provided effective security policies are in place. Excessive restrictions risk putting "tremendous roadblocks" in front of medical research, says MarkSobel, the chief of the Molecular Pathology Section at the National Cancer Institute, who helped draft the statement.

A consensus is emerging among some ethicists and scientists, however, that additional protection is needed in genetics research, and that informed consent should be required for use of nominative tissue samples. Dispensations would be given only when stringent conditions were met.

Several bills being introduced in Congress may help define the spectrum of opinion there. In the House of Representatives, Gary Condit (Democrat, California) has introduced a health information privacy bill that would give researchers access to identifiable medical records without consent, provided that studies are considered by an institutional

\section{Sandra Thurman named as new 'AIDS Czar'}

[WASHINGTON] President Bill Clinton this week nominated Sandra Thurman, the former head of a large southern US AIDS organization, as "AIDS Czar" - director of the Office of National AIDS Policy, which coordinates federal government AIDS policy.

Thurman is already a member of the president's Advisory Council on HIV/AIDS, and worked on Clinton's 1992 and 1996 election campaigns.

Thurman was for four years, until 1993, executive director of AIDS Atlanta, the largest southern AIDS service organization. It tripled in size under her directorship.

Some AIDS advocates welcomed her new appointment. "She's a strong choice. She has a good mix of history, political skills, access and tenacity," said David Smith, a review board to be "of sufficient importance so as to outweigh the intrusion into the privacy of the individual". A bill expected to be introduced this spring in the Senate by Robert Bennett (Republican, Utah) is expected to make similar recommendations.

But Representative Jim McDermott (Democrat, Washington), a psychiatrist, plans to introduce a bill that would require explicit informed patient consent for research using identifiable records or samples.

Researchers are very concerned about a bill introduced last month in the Senate by Pete Domenici (Republican, New Mexico), and cosponsored by James Jeffords (Republican, Vermont). Jeffords chairs the Senate Labor and Human Resources Committee, to which the bill has been referred. The Genetic Confidentiality and Nondiscrimination Act would discriminating on the basis of genetic information. It would also require written informed consent for any research use of genetic information, whether or not identifiable samples are involved.

Scientists argue that giving separate protection to genetic information in medical records would be impractical. Some say that the onerous bureaucratic burden the bill would create would paralyse research. But Domenici said that, under his bill, "it will only take 15-20 minutes to inform an individual and get the individual's consent - or not".

Polls show that the American public is concerned about medical records privacy, with 85 per cent calling it very important or essential. Thirty-one per cent say that it would be "not at all" acceptable for medical researchers, keeping patient identities confidential, to use records without consent. Less is known about public attitudes on stored tissue samples. But Gellman said that, on both issues, researchers risk losing a public relations battle. "The research community has a good chance of winning, but they're going to have to work at it," he said. Meredith Wadman forbid employers and health insurers from
Campaign, the largest political gay and lesbian advocacy group.

But another advocate bemoaned what he called the essential powerlessness of the position. "It has no management authority over any program that affects people with AIDS," said Gregg Gonsalves, policy director with Treatment Action Group.

Separately, a draft proposal by Clinton's Advisory Council on HIV/AIDS has called for "a significant increase in funds" for vaccine research and development. "These funds must be derived from new sources within the government and industry," the draft said. It also called for Vice-President $\mathrm{Al}$ Gore to head a new public-private vaccine advisory council. 